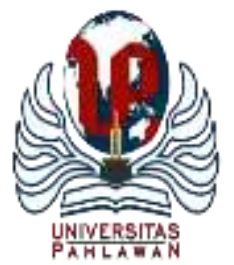

Edukatif : Jurnal Ilmu Pendidikan Volume 4 Nomor 1 Tahun 2022 Halm 548 - 555

EDUKATIF: JURNAL ILMU PENDIDIKAN

Research \& Learning in Education

https:/ledukatif.org/index.php/edukatif/index

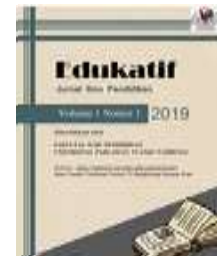

\title{
Peningkatan Keterampilan Berpikir Kritis melalui Model Problem Based Learning dalam Pembelajaran IPA di Sekolah Dasar
}

\author{
Monika Handayani ${ }^{1 凶}$, Harti Puryatmi ${ }^{2}$ Hanafi $^{3}$ \\ Universitas Terbuka, Indonesia ${ }^{1,3}$ \\ SD Negeri 2 Penolih, Indonesia ${ }^{2}$ \\ E-mail : monika@ecampus.ut.ac.id ${ }^{1}, \underline{\text { hartipuryatmi@gmail.com }}^{2}, \underline{\text { hanafi@ecampus.ut.ac.id }}^{3}$
}

\begin{abstract}
Abstrak
Pembelajaran IPA erat kaitannya dengan keterampilan berpikir kritis karena keterampilan berpikir kritis menuntut peserta didik untuk dapat mengembangkan metode ilmiah dalam penyelesaian masalah berkaitan dengan fenomena alam. Model Problem Based Learning (PBL) terkenal dengan sintaks yang menghadirkan permasalahan nyata yang dialami peserta didik sehingga peserta didik diarahkan untuk menyelesaikan permasalahan tersebut. Penelitian ini bertujuan untuk mengetahui peningkatan keterampilan berpikir kritis penggunaan model PBL pada pembelajaran IPA di SD. Jenis penelitian yang dilakukan adalah penelitian tindakan kelas. Instrumen yang digunakan adalah wawancara, observasi dan tes hasil belajar pada pembelajaran IPA. Hasil belajar pada siklus I memperoleh skor rata-rata 79,27 dan mengalami peningkatan pada siklus II dengan skor rata-rata 84,45 . Hasil observasi juga menunjukkan peserta didik pada siklus II lebih aktif dalam kegiatan kelompok dibanding pada siklus I. Berdasarkan dari hasil tes HOTS juga terjadi peningkatan pada hasil belajar peserta didik di siklus I dengan rata-rata 80,25 dan presentase KKM 66,67\% yang meningkat di siklus II dengan rata-rata 84,58 dan presentase $91,67 \%$.
\end{abstract}

Kata Kunci: problem based learning, keterampilan berpikir kritis, pembelajaran IPA.

\section{Abstract}

Science learning is closely related to critical thinking skills because critical thinking skills require students allow develop scientific methods in solving problems related to natural phenomena. The Problem Based Learning (PBL) model is famous for its syntax that presents real-life problems experienced by students so that students are directed to solve these problems. This study aims to determine the improvement of critical thinking skills using the PBL model in science learning in elementary schools. The type of research conducted is classroom action research. The instruments used are interviews, observations, and tests of learning outcomes in science learning. Learning outcomes in the first cycle obtained an average score of 79.27 and increased in the second cycle with an average score of 84.45. The results of the observations also showed that students in cycle II were more active in group activities than in cycle I. Based on the results of the HOTS test there was also an increase in the learning outcomes of learners in cycle I with an average of 80.25 and a percentage of KKM $66.67 \%$ which increased in cycle II with an average of 84.58 and a percentage of $91.67 \%$.

Keywords: problem based learning, critical thinking skills, science learning.

Copyright (c) 2022 Monika Handayani, Harti Puryatmi, Hanafi

$\triangle$ Corresponding author:

Email : monika@ecampus.ut.ac.id

DOI : https://doi.org/10.31004/edukatif.v4i1.1829

ISSN 2656-8063 (Media Cetak)

ISSN 2656-8071 (Media Online)

Edukatif : Jurnal Ilmu Pendidikan Vol 4 No 1 Tahun 2022 p-ISSN 2656-8063 e-ISSN 2656-8071 
549 Peningkatan Keterampilan Berpikir Kritis melalui Model Problem Based Learning dalam Pembelajaran IPA di Sekolah Dasar - Monika Handayani, Harti Puryatmi, Hanafi

DOI: https://doi.org/10.31004/edukatif.v4i1.1829

\section{PENDAHULUAN}

Kegiatan pembelajaran IPA di sekolah dasar menuntut peserta didik mengembangkan sikap ilmiah melalui pengamatan terhadap fenomena-fenomena alam yang terjadi di sekitarnya. Pembelajaran IPA memberikan kesempatan peserta didik untuk mengembangkan rasa ingin tahu melalui cara berpikir ilmiah terhadap fenomena alam yang terjadi (Wedyawati, N., \& Lisa, 2019). Selain itu dalam Pembelajaran IPA memerlukan kemampuan pemahaman peserta didik untuk mampu menyelesaikan masalah (Hafidz Rasyidiana, 2021). Pembelajaran IPA mendorong peserta didik memiliki cara berpikir yang ilmiah dengan menfasilitasi peserta didik memperoleh pengalaman belajar secara langsung dan nyata. Kegiatan Pembelajaran IPA yang aktif mampu mendorong peserta didik untuk mengeksplorasi pengetahuan sesuai kemampuan berpikir siswa (Wiyoko, 2019).

Keterampilan berpikir kritis merupakan salah satu keterampilan yang perlu dikembangkan dalam Pembelajaran IPA karena keterampilan ini mampu melatih peserta didik untuk mampu menyelesaikan masalah berdasarkan cara berpikir ilmiah. Berpikir kritis berkaitan dengan kualitas berpikir, kemandirian dan pengambilan keputusan pemikiran yang tepat sesuai standar yang ada (Gojkov et al., 2015) (Fitria et al., 2018). Salah satu keterampilan berpikir kritis adalah kemampuan menarik kesimpulan dengan benar berdasarkan data yang diperoleh (Ida et al., 2020). Selain itu, keterampilan berpikir kritis merupakan salah satu keterampilan 4C yang harus dikembangkan di abad 21 yang terdiri dari critical thinking, creative thinking, collaboration, dan communication. Keterampilan berpikir kritis perlu dikembangkan sejak usia sekolah dasar melalui kegiatan belajar seperti Pembelajaran IPA di SD (Zuryanty et al., 2019).

Pembelajaran IPA di SD lebih menekankan proses pemberian pengalaman belajar secara langsung melalui keterampilan proses dan sikap ilmiah (Nurmala et al., 2021). Penggunaan model Pembelajaran yang tepat dalam Pembelajaran IPA mampu menfasilitasi peserta didik memperoleh pengalaman belajar secara nyata. Model Pembelajaran Problem Based Learning (PBL) menekankan guru sebagai fasilitator yang memotivasi peserta didik untuk lebih aktif selama proses Pembelajaran (Marshel et al., 2021). Pembelajaran IPA menghadirkan permasalahan nyata yang terjadi dari fenomena yang ada di sekitar kita, Model PBL merupakan model Pembelajaran mendorong peserta didik untuk memecahkan masalah sehingga memberikan pengalaman belajar yang baru (Amini \& Helsa, 2019)

Keterampilan berpikir kritis sangat dibutuhkan peserta didik untuk melakukan serangkaian metode ilmiah yang digunakan dalam menjawab permasalahan dalam Pembelajaran IPA (Syawaludin et al., 2019). Selain itu, kemampuan-kemampuan dalam keterampilan berpikir kritis memiliki keterkaitan dengan kemampuan yang perlu dikembangkan dalam metode ilmiah. Beberapa indikator keterampilan berpikir kritis terdiri dari kemampuan untuk (1) mengidentifikasi masalah, (2) mendefinisikan masalah, (3) menentukan kebutuhan atau informasi yang diperlukan, (4) mengetahui objek atau mengeksporasi masalah dengan baik, (5) memetakan atau menentukan informasi yang tepat untuk merencanakan solusi permasalahan serta (6) merencanakan solusi permasalahan (Ariyana et al., 2018).

Model PBL adalah salah satu model yang digunakan dengan menyajikan permasalahan utama yang terjadi di sekitar peserta didik. Permasalahan yang disajikan menjadi kunci keberhasilan penerapan model PBL karena selama proses Pembelajaran peserta didik diarahkan dengan serangkaian kegiatan yang digunakan untuk menyelesaikan permasalahan tersebut. Serangkaian kegiatan dalam model PBL disebut sintaks atau Langkah kegiatan belajar. Proses dalam Langkah kegiatan belajar model PBL ini menfokuskan pada cara mencari, mengelola, menganalisis dan mengevaluasi hasil informasi yang diterima. Sintaks atau Langkah model PBL terdiri dari (1) orientasi peserta didik dalam masalah, (2) mempersiapkan peserta didik untuk belajar, (3) membimbing invesitgasi secara mandiri dan kelompok, (4) mengembangkan dan menyajikan bukti serta hasil investigasi, (5) menganalisis dan mengevalusi proses pemecahan masalah (Arends, 2015). Langkah kegiatan model PBL ini sesuai dengan proses Pembelajaran dalam keterampilan berpikir kritis. Proses 
550 Peningkatan Keterampilan Berpikir Kritis melalui Model Problem Based Learning dalam Pembelajaran IPA di Sekolah Dasar - Monika Handayani, Harti Puryatmi, Hanafi

DOI: https://doi.org/10.31004/edukatif.v4i1.1829

pembelajaran yang menitikberatkan berpikir kritis dapat mengasah kemampuan peserta didik dalam menganalisis informasi untuk mengambil keputusan yang tepat (Sriarunrasmee et al., 2015).

Selama ini kegiatan belajar yang telah dilakukan pada SD Negeri 02 Penolih belum mampu mendorong peserta didik untuk meningkatkan keterampilan berpikir kritis dalam kegiatan pembelajaran IPA. Berdasarkan dari hasil observasi diketahui bahwa guru lebih menekankan penyelesaian materi karena pembelajaran yang dilakukan selama masa pandemi adalah tatap muka terbatas. Tatap muka terbatas menyebabkan jam belajar peserta didik di sekolah menjadi berkurang akibatnya guru lebih menitikberatkan pada pemadatan materi yang dirasa guru lebih mendesak disampaikan. Akibatnya, guru lebih aktif dan peserta didik pasif terutama dalam kegiatan pembelajaran IPA peserta didik hanya menerima materi yang disampaikan dengan mencatat, merangkum dan penugasan. Hal dibuktikan dari observasi keterampilan berpikir kritis dan memecahkan masalah pada pembelajaran IPA yang masih berada disekitaran 37,5\% di bawah $50 \%$. Sedangkan, pembelajaran IPA sebenarnya tidak hanya sekedar penguasaan fakta, konsep dan prinsip tetapi juga belajar mengenai metode pemecahan masalah dan bekerja sama serta melatih keterampilan berpikir kritis untuk mengambil kesimpulan (Wedyawati, N., \& Lisa, 2019).

Berdasarkan hasil wawancara juga diketahui bahwa peserta didik belum mampu mengidentifikasi informasi yang disediakan dalam bacaan atau memilih data yang relevan yang dapat digunakan dalam kegiatan belajar. Selain itu, diketahui berdasarkan hasil wawancara dengan guru juga diketahui bahwa guru belum mencoba menggunakan model PBL pada saat tatap muka terbatas karena khawatir materi yang tersampaikan tidak sempurna Padahal jika model PBL diterapkan dengan baik oleh guru selama proses pembelajaran, peserta didik dapat mengembangkan rasa ingin tahu secara ilmiah dalam pembelajaran IPA serta melatih kemampuan bertanya dan mencari jawaban berdasarkan bukti dan cara berpikir ilmiah sehingga mampu mengembangkan rasa berpikir kritis (Christiana et al., 2014).

Berrdasarkan latar belakang tersebut, penelitian ini bertujuan untuk mengetahui sejauh mana peningkatan keterampilan berpikir kritis peserta didik melalui model PBL pada Pembelajaran Kebaruan (novelty) penelitian sebelumnya dengan penelitian ini adalah penelitian ini dilakukan disaat masa pandemi dengan sistem pembelajaran tatap muka terbatas. Kondisi tersebut yang menyebabkan pemilihan materi yang dipadatkan, penyesuaian bahan dan media ajar (RPP dan LKPD) dan model PBL harus sesuai dengan kondisi pada tatap muka terbatas.

\section{METODE PENELITIAN}

Penelitian ini adalah penelitian tindakan kelas dengan subjek penelitian adalah siswa kelas V SD Negeri 02 Penolih. Pengumpulan data yang dilakukan dengan menggunakan tes berbasis HOTS, lembar observasi guru dan peserta didik serta lembar wawancara dengan peserta didik. Penelitian ini dilakukan pada bulan Juli sampai November 2021. Desain penelitian Tindakan ini adalah Kurt \& Lewin yang terdiri dari perencanaan tindakan, pelaksanaan tindakan dengan pengamatan dan refleksi. Untuk teknik pengumpulan data dilakukan secara kuantitatif dan kualitatif. Secara kuantitatif diukur dari hasil tes berbasis HOTS yang dilakukan setiap siklus dengan kriteria keberhasilan indakan adalah jika presentase peserta didik mampu memperoleh nilai diatas KKM sebesar 75\%. Sedangkan untuk Teknik analisis data secara kualitatif dapat diukur dengan hasil observasi dan wawancara peserta didik yang menunjukkan penguasaan terhadap keterampilan berpikir kritis. Selain itu, analisis data secara kualitatif juga diukur dengan lembar observasi guru dalam mengaplikasikan model PBL.

\section{HASIL DAN PEMBAHASAN PENELITIAN}

\section{Hasil Penelitian}

Penelitian ini dimulai dari tahap pra tindakan dengan melakukan observasi dan wawancara terhadap peserta didik kelas V SD N 02 Penolih. Lembar observasi yang digunakan adalah ceklist dengan pilihan 
551 Peningkatan Keterampilan Berpikir Kritis melalui Model Problem Based Learning dalam Pembelajaran IPA di Sekolah Dasar - Monika Handayani, Harti Puryatmi, Hanafi

DOI: https://doi.org/10.31004/edukatif.v4i1.1829

jawaban Ya dan tidak dan indikator penilaian didasarkan pada indikator kemampuan dalam keterampilan berpikir kritis. Pada tahap pra tindakan diketahui berdasarkan hasil observasi yang telah dilakukan keterampilan berpikir kritis peserta didik masih berada di bawah 50\% dengan kemampuan yang paling rendah adalah menentukan kebutuhan atau informasi yang diperlukan. Selanjutnya dari hasil wawancara juga diketahui bahwa peserta didik kesulitan untuk memilih informasi yang relevan dalam teks bacaan untuk menjawab pertanyaan yang diajukan oleh guru. Peserta didik juga mengaku tergantung dengan petunjuk dari guru untuk mampu menjawab pertanyaan yang diberikan sehingga guru lebih aktif selama proses Pembelajaran karena guru yang memberikan petunjuk.

Selanjutnya dilakukan Tindakan dengan penggunaan model PBL dalam kegiatan belajar di siklus I dilakukan perencanaan pembuatan RPP sesuai sintaks model PBL. Selain itu, pada tahap perencanaan di siklus I adalah pembuatan LKPD dan media yang digunakan disesuaikan dengan materi. Pada siklus I, guru melakukan kegiatan belajar menggunakan model PBL dibantu dengan penggunaan LKPD dan media gambar serta video. Sedangkan untuk Teknik pengumpulan data yang digunakan adalah lembar observasi dan wawancara peserta didik serta tes berbasis HOTS. Peserta didik pada siklus I ini jauh lebih aktif dibandingkan pada tahap pra tindakan, karena pada siklus I peserta didik bekerja dalam kelompok kecil untuk memecahkan permasalahan. Selain itu, pada siklus I guru lebih berperan sebagai fasilitator dan memotivasi peserta didik dalam bekerja sama menemukan solusi dari permasalahan yang disajikan. Hasil tes HOTS yang di siklus I juga belum mampu memenuhi KKM.

Refleksi pada kegiatan siklus I adalah kurang maksimalnya guru dalam menerapkan sintaks model PBL terutama pada Langkah mengorientasikan peserta didik kepada masalah dan langkah mengembangkan dan menyajikan bukti. Pada Langkah orientasi peserta didik kepada masalah seharusnya guru mendorong peserta didik memunculkan permasalahan tetapi pada prakteknya guru yang menyajikan permasalahan tersebut. Sedangkan pada Langkah mengembangkan dan menyajikan bukti, guru belum mampu sepenuhnya membimbing peserta didik untuk mengembangkan bukti dan hasil investigasi. Berdasarkan hasil wawancara juga diketahui peserta didik masih kesulitan dalam mengembangkan argumen atau penjelasan logis pemilihan informasi yang dapat digunakan untuk menyelesaikan permasalahan tersebut.

Berdasarkan hasil refleksi pada kegiatan di siklus I, maka kegiatan perencanaan pada siklus II adalah menyiapkan RPP dengan sintaks model PBL, menyiapkan media yang sesuai dengan materi (gambar dan video), dan menyiapkan RPP berbasis model PBL yang dapat digunakan sebagai Pedoman peserta didik dalam kegiatan Pembelajaran. Pelaksanaan di siklus II lebih baik dibanding siklus I, karena pada siklus II guru lebih sempurna dalam menerapkan Langkah model PBL terutama pada Langkah orientasi terhadap masalah dan pengembangan atau penyajian bukti. Berdasarkan hasil observasi diperoleh bahwa guru mampu berperan secara penuh sebagai fasilitator yang membimbing peserta didik terutama pada kegiatan di kelompok. Selain itu, berdasarkan hasil wawancara juga diketahui peserta didik merasa lebih mudah dalam mengikuti sintaks model PBL dengan berbantuan LKPD serta lebih mudah menemukan informasi yang dapat digunakan untuk menyelesaikan permasalahan. Berdasarkan hasil observasi juga diketahui jika indikator kemampuan pada keterampilan berpikir kritis peserta didik juga lebih tinggi dibanding siklus I begitu pula dengan hasil tes HOTS yang diberikan sudah memenuhi KKM. Berikut disajikan tabel 1 mengenai peningkatan hasil tes HOTS peserta didik di siklus I dan II.

Tabel 1

Hasil Tes HOTS Peserta Didik

\begin{tabular}{lllll}
\hline Jenis Siklus & Nilai Terendah & Nilai Tertinggi & Rata-Rata & Presentase KKM \\
\hline Siklus I & 53 & 100 & 80,25 & $66,67 \%$ \\
\hline Siklus II & 53 & 100 & 84,58 & $91,67 \%$ \\
\hline
\end{tabular}

Hasil tes HOTS pada siklus I presentasi KKM yang dicapai $66,67 \%$ belum memenuhi kriteria keberhasilan tindakan yang memiliki $75 \%$ presentase KKM. Sedangkan untuk rata-rata siklus I adalah 80,25 
552 Peningkatan Keterampilan Berpikir Kritis melalui Model Problem Based Learning dalam Pembelajaran IPA di Sekolah Dasar - Monika Handayani, Harti Puryatmi, Hanafi

DOI: https://doi.org/10.31004/edukatif.v4i1.1829

dengan nilai tertinggi 100 dan nilai terendah 53. Pada siklus II, hasil tes HOTS meningkat presentasenya menjadi $91,67 \%$ dengan rata-rata 84,58 dan nilai terendah 53 serta nilai tertinggi 100. Hasil tes HOTS di siklus II telah mencapai kriteria keberhasilan tindakan karena presentase nilai KKM lebih dari $75 \%$. Hasil ini sejalan dengan penelitian yang telah dilakukan bahwa model PBL telah diakui karena mampu mengembangkan keterampilan HOTS dan keterampilan pemecahan masalah dalam komunitas professional (Yeo \& Tan, 2014).

Peningkatan hasil juga terjadi pada hasil observasi keterampilan berpikir kritis peserta didik. Observasi dilakukan mulai pada tahap pra tindakan dan diketahui bahwa keterampilan berpikir kritis peserta didik masih berada dipresentase 37,5\% dan masuk kategori rendah. Pada siklus I, keterampilan berpikir kritis peserta didik ini meningkat menjadi presentase $66,67 \%$ dan pada siklus II Kembali meningkat menjadi 80,55\%. Untuk lebih jelasnya berikut disajikan gambar 1 berisi diagram batang peningkatan hasil observasi keterampilan berpikir kritis peserta didik.

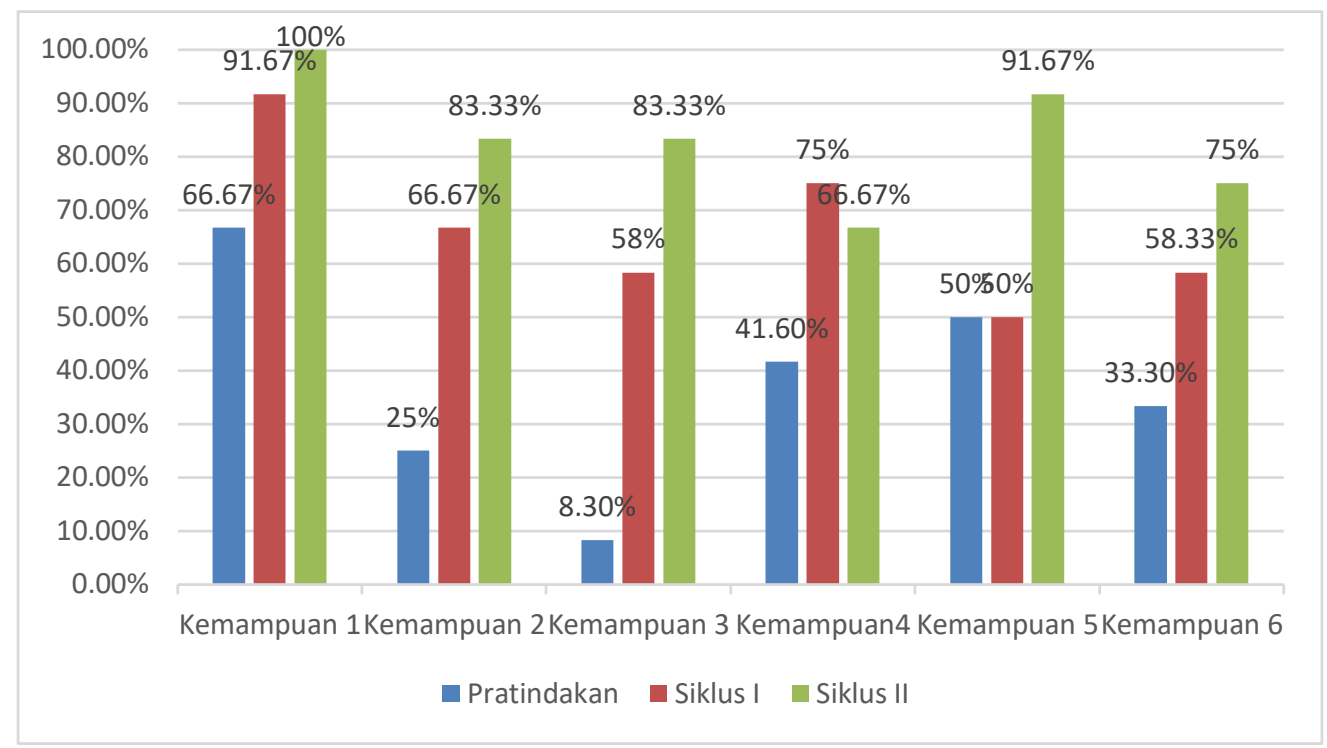

\section{Gambar 1. Diagram Batang Hasil Observasi Keterampilan Berpikir Kritis}

Diagram batang tersebut menunjukkan bahwa setiap indikator kemampuan dalam keterampilan berpikir kritis meningkat di mulai dari tahap pra tindakan sampai siklus II. Namun terdapat satu indikator kemampuan yang mengalami penurunan di siklus II yaitu mengetahui objek atau mengeksplorasi masalah dengan baik. Hal ini disebabkan karena peserta didik masih kesulitan memberikan batasan terhadap informasi yang diperoleh untuk menyelesaikan masalah. Kesulitan ini menjadi refleksi di siklus II supaya guru lebih dapat membimbing peserta didik terutama pada saat mengeksplorasi masalah dengan baik. Tingkat presentase di siklus II yang lebih dari 75\% maka dapat diketahui bahwa model PBL mampu meningkatkan keterampilan berpikir kritis. Sesuai penelitian yang telah dilakukan (Zuryanty et al., 2019) membuktikan bahwa penggunaan model PBL dalam Pembelajaran IPA di SD dapat meningkatkan keterampilan berpikir kritis.

\section{Pembahasan}

Pada tahap pra tindakan diketahui bahwa indikator kemampuan dari keterampilan berpikir kritis peserta didik masih di bawah 50\%. Hasil tersebut meningkat pada siklus I dan siklus II dengan penggunaan model PBL. Hal ini membuktikan bahwa keterampilan berpikir kritis peserta didik dapat ditingkatkan melalui serangkaian aktivitas kegiatan Pembelajaran pada model PBL terutama pada saat peserta didik dihadapkan dengan permasalahan yang nyata di sekitarnya. Selain itu, model PBL juga mendorong peserta didik untuk aktif dalam berkolaborasi dan memecahkan masalah (Dakabesi \& Luoise, 2019). Serangkaian kegiatan dalam model PBL tersebut mampu mendorong peserta didik untuk aktif menggunakan keterampilan berpikir 
553 Peningkatan Keterampilan Berpikir Kritis melalui Model Problem Based Learning dalam Pembelajaran IPA di Sekolah Dasar - Monika Handayani, Harti Puryatmi, Hanafi

DOI: https://doi.org/10.31004/edukatif.v4i1.1829

kritisnya mulai dari proses menjawab permasalahan di awal, pengumpulan informasi, strategi penyelesaian masalah, analisis, argument dan kesimpulan (Fitriyah \& Ghofur, 2021)

Selain peningkatan dari hasil observasi keterampilan berpikir kritis, peningkatan lainnya terlihat dari hasil belajar dari tes HOTS pada pembelajaran IPA yang pada siklus II meningkatkan presentase KKM menjadi 91,67\%. Hasil tersebut membuktikan bahwa Pembelajaran IPA di sekolah dasar erat kaitannya dengan penggunaan model PBL, karena karena model PBL mampu menghadirkan permasalahan yang nyata sehingga menfasilitasi peserta didik untuk aktif terlibat memecahkan masalahnya. Pembelajaran IPA lebih menekankan pada konsep masalah sehingga peserta didik dilatih untuk menemukan sendiri konsep yang dipelajari melalui pengalaman langsung (Amini \& Helsa, 2019). Dalam model PBL, peserta didik mulai belajar ketika dihadapkan pada suatu permasalahan nyata sehingga seluruh informasi yang diperoleh dilakukan untuk menyelesaikan permasalahan tersebut (Gallagher et al., 1995) .

Penelitian ini dilakukan untuk mengetahui peningkatan keterampilan berpikir kritis menggunakan model PBL dalam pembelajaran IPA SD. Sebelumnya telah banyak penelitian tindakan mengenai model PBL yang mampu meningkatkan kompetensi berpikir kritis dan kemampuan memecahkan masalah (Sholihah \& Lastariwati, 2020) (Lutfiah et al., 2021) (Rahmawati, 2021) Selain itu, penelitian lain juga menunjukkan model Problem Based Learning lebih efektif untuk mendorong keterampilan berpikir kritis dibanding problem posing (Sasmita \& Harjono, 2021). Beberapa hasil penelitian meta analisis juga menunjukkan bahwa model PBL mampu meningkatkan kemampuan berpikir kritis dan kolaboratif (Kong et al., 2014) (Rossytasari \& Setyaningtyas, 2021). Berdasarkan hasil beberapa penelitian tersebut membuktikan bahwa model PBL mampu mendorong keterampilan berpikir kritis peserta didik dan sesuai dengan hasil yang diperoleh dalam penelitian ini.

\section{KESIMPULAN}

Berdasarkan dari hasil yang diperoleh pada siklus I dan II dapat diketahui bahwa model PBL mampu meningkatkan keterampilan berpikir kritis dalam pembelajaran IPA di SD. Hal tersebut dibuktikan berdasarkan hasil tes kemampuan HOTS peserta didik dan hasil observasi mengenai keterampilan berpikir kritis yang mampu mencapai kriteria keberhasilan tindakan. Keterampilan berpikir kritis mampu meningkat dengan serangkaian aktivitas atau kegiatan belajar yang mendorong peserta didik untuk memecahkan masalah yang nyata dan mengevaluasi hasil pemecahan masalah yang telah dilakukan.

\section{UCAPAN TERIMA KASIH}

Penulis ucapkan terima kasih kepada LPPM Universitas Terbuka atas kesempatan dan ijin yang diberikan untuk melaksanakan penelitian dalam rangka memenuhi tri dharma Dosen. Ucapan terima kasih juga disampaikan kepada Kepala SD N 02 Penolih atas ijin yang diberikan pada proses pelaksanaan penelitian sehingga penelitian yang telah dilakukan dapat berlangsung dengan lancar dan sukses.

\section{DAFTAR PUSTAKA}

Amini, R., \& Helsa, Y. (2019). The Development of Problem-Based Learning Material for Integrated Science Subject in Primary Teacher Education Program. Journal of Physics: Conference Series, 1280(3), 1-7. https://doi.org/10.1088/1742-6596/1280/3/032053

Arends, R. I. (2015). Learning to Teach (Tenth Edition). In McGraw-Hill Education: Vol. Tenth Edit.

Ariyana, Y., Widyaiswara, Ari Pudjiastuti MPd Widyaiswara, Reisky Bestary, M., \& Widyaiswara, Zamroni, Mp. (2018). Buku Pegangan Pembelajaran Berorientasi pada Keterampilan Berpikir Tingkat Tinggi.

Christiana, P. P., Suniasih, N. W., \& ... (2014). Pengaruh Model Problem Based Learning Berbasis Penilaian Proyek terhadap Kemampuan Berpikir Kritis IPA SD Gugus VIII Sukawati. Mimbar Pgsd .... https://ejournal.undiksha.ac.id/index.php/JJPGSD/article/view/2031\%0Ahttps://ejournal.undiksha.ac.id/ 
554 Peningkatan Keterampilan Berpikir Kritis melalui Model Problem Based Learning dalam Pembelajaran IPA di Sekolah Dasar - Monika Handayani, Harti Puryatmi, Hanafi

DOI: https://doi.org/10.31004/edukatif.v4i1.1829

index.php/JJPGSD/article/download/2031/1771

Dakabesi, D., \& Luoise, I. S. Y. (2019). The effectiveness of problem-based learning model to increase the students' critical thinking skills. Journal of Education and Learning (EduLearn), 13(4), 543-549. https://doi.org/10.11591/edulearn.v13i4.12940

Fitria, Y., Hasanah, F. N., \& Gistituati, N. (2018). Critical Thinking Skills of Prospective Elementary School Teachers in Integrated Science-Mathematics Lectures. Journal of Education and Learning (EduLearn), 12(4), 597-603. https://doi.org/10.11591/edulearn.v12i4.9633

Fitriyah, I. M. N., \& Ghofur, M. A. (2021). Pengembangan E-LKPD Berbasis Android dengan Model Pembelajaran Problem Based Learning (PBL) untuk Meningkatkan Berpikir Kritis Peserta Didik. Edukatif: Jurnal Ilmu Pendidikan, 3(5), 1957-1970. https://edukatif.org/index.php/edukatif/article/view/718/pdf

Gallagher, S. A., Sher, B. T., Stepien, W. J., \& Workman, D. (1995). Implementing Problem-Based Learning in Science Classrooms. School Science and Mathematics, 95(3), 136-146. https://doi.org/10.1111/j.1949-8594.1995.tb15748.x

Gojkov, G., Stojanović, A., \& Rajić, A. G. (2015). Critical Thinking of Students - Indicator of Quality in Higher Education. Procedia - Social and Behavioral Sciences, 191(2012), 591-596. https://doi.org/10.1016/j.sbspro.2015.04.501

Hafidz Rasyidiana. (2021). Problematika Pembelajaran Daring Pada Mata Pelajaran Sains (IPA) Tingkat Dasar Di Masa Pandemi Covid-19. Jurnal Basicedu, 5(4), 1060-1066.

Ida, P., Dewi, A., Tinggi, S., Hindu, A., Mpu, N., \& Singaraja, K. (2020). Pengembangan Pembelajaran Berbasis Hots Dalam Meningkatkan Kemampuan Analisis Mata Kuliah Pembelajaran Ips Sekolah Dasar. Jurnal Widyacarya, 4(1), 93-97.

Kong, L. N., Qin, B., Zhou, Y. qing, Mou, S. yu, \& Gao, H. M. (2014). The effectiveness of problem-based learning on development of nursing students' critical thinking: A systematic review and meta-analysis. International Journal of Nursing Studies, 51(3), 458-469. https://doi.org/10.1016/j.ijnurstu.2013.06.009

Lutfiah, W., Hambali, H., \& Makassar, U. M. (2021). EDUKATIF : JURNAL ILMU PENDIDIKAN Pengaruh Model Pembelajaran Problem Based Learning terhadap Hasil Belajar Biologi. 3(4), 2092-2098.

Marshel, J., Ratnawulan, \& Fauzi, A. (2021). Practicality of student worksheets science based on problem based learning models with the theme of the motion in life using integrated connected type 21 stcentury learning. Journal of Physics: Conference Series, 1876(1), 1-9. https://doi.org/10.1088/1742$6596 / 1876 / 1 / 012050$

Nurmala, S., Triwoelandari, R., \& Fahri, M. (2021). Pengembangan Media Articulate Storyline 3 pada Pembelajaran IPA Berbasis STEM untuk Mengembangkan Kreativitas SiswaSD/MI Siti Nurmala $1 \square$, Retno Triwoelandari 2 , Muhammad Fahri 3. 5(6), 5024-5034.

Rahmawati, E. (2021). Application of the Problem Based Learning Model to Improve Critical Thinking Skills for Grade IV Elementary School Students. Social, Humanities, and Educational Studies (SHEs): Conference Series, 3(4), 104. https://doi.org/10.20961/shes.v3i4.53289

Rossytasari, I. O., \& Setyaningtyas, E. W. (2021). Meta Analisis Model Problem Based Learning (PbL) terhadap Kemampuan Berpikir Kritis Siswa Sekolah Dasar. Edukatif: Jurnal Ilmu ..., 3(4), 2067-2080. https://edukatif.org/index.php/edukatif/article/view/1135

Sholihah, T. M., \& Lastariwati, B. (2020). Problem based learning to increase competence of critical thinking and problem solving. Journal of Education and Learning (EduLearn), 14(1), 148-154. https://doi.org/10.11591/edulearn.v14i1.13772

Sriarunrasmee, J., Suwannatthachote, P., \& Dachakupt, P. (2015). Virtual Field Trips with Inquiry learning and Critical Thinking Process: A Learning Model to Enhance Students' Science Learning Outcomes. Procedia - Social and Behavioral Sciences, 197(February), 1721-1726. 
555 Peningkatan Keterampilan Berpikir Kritis melalui Model Problem Based Learning dalam Pembelajaran IPA di Sekolah Dasar - Monika Handayani, Harti Puryatmi, Hanafi

DOI: https://doi.org/10.31004/edukatif.v4i1.1829

https://doi.org/10.1016/j.sbspro.2015.07.226

Syawaludin, A., Gunarhadi, \& Rintayati, P. (2019). Development of augmented reality-based interactive multimedia to improve critical thinking skills in science learning. International Journal of Instruction, 12(4), 331-344. https://doi.org/10.29333/iji.2019.12421a

Wedyawati, N., \& Lisa, Y. (2019). Pembelajaran IPA di Sekolah Dasar. Deepublish.

Wiyoko, T. (2019). Analisis Profil Kemampuan Berpikir Kritis Mahasiswa PGSD Dengan Graded Response Models Pada Pembelajaran IPA Analysis Of Capability Profile Of Critical Thinking Of PGSD Students With Graded Response On Science Learning. Ijis Edu, 1(1), 25-32.

Zuryanty, Kenedi, A. K., Chandra, R., Hamimah, \& Fitria, Y. (2019). Problem based learning: A way to improve critical thinking ability of elementary school students on science learning. Journal of Physics: Conference Series, 1424(1), 1-5. https://doi.org/10.1088/1742-6596/1424/1/012037 